Gadjah Mada International Journal of Business

May-August 2008, Vol. 10, No. 2, pp. 261-280

\title{
OUTPUT-PRICE DYNAMICS IN THE ASEAN-5 COUNTRIES:

\author{
Evidence from The Pre- and Post-1997 \\ Financial Turmoil
}

Salina Hj. Kassim

M. Shabri Abd. Majid

\begin{abstract}
We analyze the cyclical behavior between outputs and prices in major ASEAN economies, namely Malaysia, Indonesia, Thailand, Singapore and the Philippines over two sample periods: the precrisis period (1990 to 1996) and the post-crisis period (2000 to 2006). Specifically, the study aims to shed the light on two issues: (i) the possibility that there is a change in the patterns of the correlations between real activities and prices in a particular country in the pre-crisis period compared to the post-crisis period; and (ii) the synchronization of real activity and price relationships or the business cycles across the major ASEAN countries. In order to analyze the output-price relationship across the countries and time periods, we adopt several tests including the Pearson correlation analysis, Auto-Regressive Distributed Lag (ARDL) model and Vector Error-Correction Model (VECM). The study documents that the output-price relationship has changed in several countries following the crisis in 1997/1998. While there is a clear business cycles synchronization between the ASEAN-5 countries in the short-run, results have been mixed in the long run. Results of this study contribute towards further enriching the policy recommendations to help ensuring the viability and effectiveness of the economic cooperation between the ASEAN nations.
\end{abstract}

Keywords: ARDL; ASEAN; economic cooperation; output-price dynamics; VECM

JEL Classifications: C32, E31, E32, O47 
Gadjah Mada International Journal of Business, May - August 2008, Vol. 10, No. 2

\section{Introduction}

A clear understanding on the relationship between output and price in an economy is crucial particularly to the policymakers in ensuring effective macroeconomic stabilization policies can be designed and implemented. Traditional business cycle models propose that output and prices are procyclical or simply, positively related (for example, Moore 1983; Zarnowitz and Moore 1983). The pro-cyclical behavior of output and price implies that demand-side disturbances are the primary source of the macroeconomic fluctuations in the economy. Increase in aggregate demand due to unexpected increase in government spending or money supply results in positive price surprises, thus increasing output and price in the short run - a phenomenon called "demand-pull" inflation. The identification of the demand shocks as the predominant cause of macroeconomic fluctuations entails that macropolicies based on the Keynesian framework are effective policy interventions to stabilize the economy. Based on this framework, discretionary policy intervention is most suitable to stabilize the economy as economic fluctuations are just temporary deviations around a stable, full employment level of output (Phelps 1967; Friedman 1968).

While the pro-cyclical behavior of price and output has been widely accepted as the conventional or textbook explanation to the behavior of the two variables, empirical evidences however, seem to indicate the oppo- site. This competing view of the output-price relationship is known as the real business-cycle model which proposes a negative relation between output and price, that is, as price increases, total output will decrease. In essence, the real business-cycle model emphasizes the predominance of supply-side shocks in causing macroeconomic fluctuations. In contrast to demand shock which is increase in output due to unanticipated price changes, supplyside theory maintains that output varies with anticipated price changes. For instance, anticipated changes in energy prices increase the cost of production, decreasing output and raising prices - a phenomenon called "costpush" inflation. This model finds rich empirical support to its proposition. Kydland and Prescott (1990) document the anti-cyclical behavior of output and prices in the US in the postKorean War period. Several other studies including Cooley and Ohanian (1991), Backus and Kehoe (1992) and Smith (1992) also show similar findings. Their findings are robust and conclusive with an extended sample sizes in terms of time period and across countries. While discretionary policy is proposed to be the effective policy framework if demand-side shocks are predominant in causing macroeconomic fluctuations, policy rules (as advocated by the monetarists) work better when supply-side shocks exert major influence on macroeconomic activities. This policy framework works better than the discretionary framework since the main source of 
macroeconomic fluctuation comes from the optimal response of economic agents to unforeseen supply side shocks. Therefore, to reduce the uncertainties, adherence to simple monetary policy rule is proposed.

Consistently throughout the literature, the direction of causality is not being highlighted. The issue of contention here is on the nature of the relationship, either positive (that is pro-cyclical) or negative (that is anticyclical) since it has significant implication on the type of macroeconomic stabilization policy to be implemented.

If output and price are positively related (pro-cyclical), then it signifies the importance of demand in pulling output, highlighting the dominance of the consumption side in driving the economic activity. Thus, effective economic policy during an economic downturn would be to stimulate aggregate demand (such as consumer demand or external demand through supportive export policies).

On the other hand, if output and price are negatively related (anti-cyclical), it signifies that output contracted when prices increase, which highlight the importance of the production side of the economy. Due to this nature of the economy, effective economic policy during an economic downturn would be to formulate policies that are more supportive of the production side (such as giving tax incentive to the corporate to reduce cost of doing business or giving subsidies for the raw materials in efforts to reduce the costs of inputs). In essence, identification of the relationship between output and price enables the policymakers to identify the major source of macroeconomic fluctuations and is the key to effective policy prescriptions to stabilize the economy. In the context of economic grouping, clear understanding of the relationship between real activity and price in the member countries is even more crucial, particularly in considering for the possibility of macroeconomic policy harmonization.

This study attempts to determine the cyclical behavior between output and price in major ASEAN economies, namely Malaysia, Indonesia, Thailand, Singapore and the Philippines. While incorporating all the ASEAN members in the study would result in a more useful, what's more to suggest policy recommendations for the ASEAN, the major stumbling block in including all 11 ASEAN members is the availability and constancy of data. Complete data set based on a monthly frequency for the period from 1990 to 2006 can only be found for these five countries. In addition, since these five pioneering ASEAN countries contribute around 60 percent of ASEAN total gross domestic product (GDP); these countries could be a good representative of ASEAN as a whole.

In terms of sample period, this study considers two sample periods, namely the pre-crisis period (1990 to 1996) and the post-crisis period (2000 to 2006). In doing so, this study aims to shed the light on a number of issues; first, to empirically identify the major 
Gadjah Mada International Journal of Business, May - August 2008, Vol. 10, No. 2

source of macroeconomic fluctuations in these countries; second, to identify if there is a change in the patterns of the correlation between output and price in the pre-crisis period compared to the post-crisis period in these economies; and third, to find empirical support of the existence of synchronization in the business cycles across these countries.

Using several tests, the study hopes to provide conclusive empirical evidence on the nature of output-price relationship in the ASEAN-5 countries. The benefit of conducting several tests is that it would enable us to arrive at more conclusive evidence, particularly when the results are consistent based on the several tests. If we rely on just one test, the results being presented might not be reliable and convincing. The findings of the study would contribute towards effective recommendations with regard to the critical factors to be emphasized in increasing the degree of economic integration within the ASEAN nations and the relevant policy framework in implementing macroeconomic stabilization policy in these countries. Ultimately, the results of this study evaluate the possibility of macroeconomic policy harmonization in the ASEAN context, in particular the viability of the establishment of the proposed Asian Economic Community 2015.

The rest of the paper is organized as follows: the next section surveys the literature on the cyclical behavior of output and price in various countries and economic groupings. Section
3 highlights the data preliminaries and empirical methods of the study, while Section 4 discusses the empirical findings. Finally, Section 5 summarizes the main results and draws several policy implications from the study.

\section{Literature Review}

In view of its importance in the area of macroeconomics, understanding the cyclical behavior of output and price has captured the interest of many researchers. In general, empirical studies have shown that the nature of output-price relationship varies across countries and time periods. Studies focusing on the US case have widely shown that output and price are negatively correlated. Kydland and Prescott (1990) found negative correlation between output and price in the US in the period 1954-1989. Cover and Hueng (2001) also find similar findings in their study of the US case over an extended sample period from 1876 to 1999. Using the bivariate GARCH error process based on the VAR methodology, the study documents the timevarying property of the cyclical behavior of output and price. In particular, output-price correlation is found to be positive before the 1945 period, and turned negative in the post-1964 period. Another important finding is that the estimated correlation is typically positive during economic recession and negative during economic expansion. Other supporting studies include that of Wolf (1991), Cooley and Ohanian (1991), Smith (1992) and Chada and 
Prasad (1993). In view of the substantial evidence on the negative relationship between output and price, Kydland and Prescott (1990) confirmed that the relationship between output and price in the US in the post-war period is counter-cyclical.

Den Haan and Sumner (2001) study the short-run and long-run comovement between output and price in the G7 countries, namely Canada, France, Germany, Italy, Japan, United Kingdom and the US using VAR forecast errors and frequency domain filters. Using industrial production index to represent output and consumer price index to represent price, the study finds several patterns of correlation between output and price across all the countries. In particular, the outputprice relationship is found to be significantly negative in the long run and significantly higher in the short run. Several other studies on the developed countries which show similar results include Fiorito and Kollintzas (1994) for the G7 countries and Backus and Kehoe (1992) for ten OECD countries. These studies support that prices were pro-cyclical in the pre-war period but turned counter-cyclical in the post-war period.

Recent studies in this area apply more sophisticated econometric techniques to arrive at more conclusive findings. Lee (2006) uses the Engle's (2002) dynamic conditional correlation-GARCH model, which represent a significant methodological departure from the existing literature. Based on the sample period $1900-2002$, the study confirms that the time varying property of the US output-price relationship such that they tend to be procyclical in the pre-war period and anticyclical in the post-war period.

To our knowledge, output-price relationship investigation has been somewhat scarce for the Asian countries. Kim (1996) investigates the output-price relationship in two Asian economies, namely Korea and Taiwan and finds that price index is negatively correlated with output, while inflation is positively correlated with output. For Korea, Yoo (1992) finds negative relationship between output and price, while Jun (1992) supports the procyclical behavior between the two.

\section{Data and Methodology}

\section{Data Sources}

In efforts to investigate the relationship between output and price in the major ASEAN economies, we use the Industrial Production Index (IPI) to represent real economic activity and the Consumer Price Index (CPI) to represent price. While data for the CPI are consistently available for all the countries during the period under review, this is not the case for the IPI. In cases where data on industrial production are not available, we use the manufacturing index instead. In the special case of Thailand where both industrial production index and manufacturing index data are not available for the period under review, we use the export data as a proxy for output of the real 
Gadjah Mada International Journal of Business, May - August 2008, Vol. 10, No. 2

sector. Inflation is calculated by changes in the CPI, while real output is derived by taking the logarithm of industrial output divided by inflation. All data are gathered from the International Financial Statistics database 2007 published by the International Monetary Fund.

In terms of sample period, the study focuses on the period from 1990:Q1 to 2006:Q4, where this sample period is further divided into the precrisis period (1990:Q1 - 1996:Q4) and post-crisis period (2000:Q1 2006:Q4). The selection of sample period takes into account a number of considerations. Apart from data availability on quarterly basis which only starts from 1990, we also incorporate and analyze the latest data to ensure the most recent findings. Thus, the sample period ends at 2006. In addition, to ensure consistency of our analysis, we exclude the highly volatile period during the Asian financial crisis $1997 / 1998$ as well as the recovery period in 1999. Therefore, the second sample period spanned from 2000 to 2006. In short, we analyze six years before the crisis and six years after the crisis.

\section{Methodology}

Pearson Correlation Coefficient. The Pearson correlation analysis is undertaken to analyze the short-run relationship between output and price in the ASEAN-5 countries. The analysis helps to quantify the relationship between the variables and at the same time indicate the strength and direc- tion of the relationship between the variables.

Autoregressive Distributed Lag (ARDL) Bound Testing Approach. In this study, the short- and long-run dynamic relationships between output and price are estimated by using the ARDL bound testing approach which was initially introduced by Pesaran et al. (1996). The ARDL approach is adopted due to its numerous advantages. First, unlike the most widely used method for testing cointegration, the ARDL approach can be applied regardless of the stationary properties of the variables in the samples and allows for inferences on long-run estimates. In other words, this procedure can be applied irrespective of whether the series are $I(0), I(1)$, or fractionally integrated (Pesaran and Pesaran 1997; and Bahmani-Oskooee and Ng 2002), thus avoids the problems resulting from non-stationary time series data (Laurenceson and Chai 2003). Second, the ARDL model takes sufficient numbers of lags to capture the data generating process in a general-to-specific modeling framework (Laurenceson and Chai 2003). It estimates $(p+1)^{\mathrm{k}}$ number of regressions in order to obtain optimal lag-length for each variable, where $p$ is the maximum lag to be used, and $k$ is the number of variables in the equation. Finally, the ARDL approach provides robust results for a smaller sample size of cointegration analysis. Since the sample size of our study is 28 (for each period), this provides more motivation for the study to adopt the ARDL model. 
Kassim \& Abd. Majid-0utput-Price Dynamics in the ASEAN-5 Countries

In this study, the ARDL model used for the individual country's output-price relationship can be written as follow:

$$
\begin{aligned}
& Y_{\text {it }}=\alpha_{0}+\alpha_{1} I N F_{i t}+e_{t} \\
& I_{\text {INF }}=\alpha_{0}+\alpha_{1} Y_{i t}+e_{t} .
\end{aligned}
$$

The error correction version of ARDL framework pertaining to the variables in Equations (1) and (2) can be reproduced as follows:

$$
\begin{aligned}
\Delta \mathrm{Y}_{\mathrm{it}}= & \delta_{0}+\sum_{\mathrm{i}=1}^{\mathrm{p}} \varepsilon_{\mathrm{i}} \Delta \mathrm{Y}_{\mathrm{it}-\mathrm{i}}+\sum_{\mathrm{i}=0}^{\mathrm{p}} \phi_{\mathrm{i}} \Delta \mathrm{INF}_{\mathrm{it}-\mathrm{i}}+ \\
& \lambda_{1} \mathrm{Y}_{\mathrm{it}-\mathrm{i}}+\lambda_{2} \mathrm{INF}_{\mathrm{it}-\mathrm{i}}+\mathrm{u}_{1 \mathrm{t}} \ldots \ldots . .(3)
\end{aligned}
$$

$$
\begin{array}{r}
\Delta \mathrm{INF}_{\mathrm{it}}=\delta_{0}+\sum_{\mathrm{i}=1}^{\mathrm{p}} \varepsilon_{\mathrm{i}} \Delta \mathrm{INF}_{\mathrm{it}-\mathrm{i}}+\sum_{\mathrm{i}=0}^{\mathrm{p}} \phi_{\mathrm{i}} \Delta \mathrm{Y}_{\mathrm{it}-\mathrm{i}}+ \\
\lambda_{1} \mathrm{INF}_{\mathrm{it}-\mathrm{i}}+\lambda_{2} \mathrm{Y}_{\mathrm{it}-\mathrm{i}}+\mathrm{u}_{1 \mathrm{t}} \ldots \ldots . .(4)
\end{array}
$$

The terms with the summation signs in the Equations (3) and (4) represent the error correction dynamic, while the second part (term with $\lambda s$ ) correspond to the long run relationship. The null of no cointegration in the long run relationship is defined by $H_{0}: \lambda_{1}=\lambda_{2}=$ 0 is tested against the alternative of $H_{1}$ : $\lambda_{1} \neq \lambda_{2} \neq 0$, by the means of F-test. However, the asymptotic distribution of this F-statistic is nonstandard irrespective of whether the variables are $I(0)$ or $I(1)$. For a small sample size study which is less than 80 observations, Narayan (2004) has tabulated two sets of appropriate critical values.
As a result, this study uses Narayan (2004) critical values instead of that of Pesaran et al. (1996). One set assumes all variables are $I(1)$ and another assumes that they are all $I(0)$. This provides a bound covering all possible classifications of the variables into $I(1)$ and $I(0)$ or even fractionally integrated. If the F-statistic lies exceeds upper bound level, the null hypothesis is rejected, which indicates the existence of cointegration. On the other hand, if the F-statistic falls below the bound level, the null hypothesis cannot be rejected, which supporting no cointegration exist. If, however, it falls within the band, the result is inconclusive.

Finally, in order to determine the optimal lag-length incorporated into the model and select the ARDL model to be estimated, the study employs the Schwartz Bayesian Criteria (SBC). Since our study utilizes quarterly data with only 28 numbers of observations, the possible optimal lag-length to be considered is 6 .

Vector Error Correction Model Framework. To examine the shortand long-run dynamic relationships of the variables among the countries, the study employs the Vector Error Correction Model (VECM) framework. The VECM regresses the changes in the both dependent and independent variables on lagged deviations. The multivariate causality test based on VECM can therefore be formulated as follows: 
Gadjah Mada International Journal of Business, May - August 2008, Vol. 10, No. 2

$$
\begin{aligned}
\Delta \mathrm{Z}_{\mathrm{t}}= & \delta+\Gamma_{\mathrm{i} \Delta} \mathrm{Z}_{\mathrm{t}-1}+\ldots+\Gamma_{\mathrm{k} \Delta} \mathrm{Z}_{\mathrm{t}-\mathrm{k}} \\
& +\Pi \mathrm{Z}_{\mathrm{t}-\mathrm{k}}+\varepsilon_{\mathrm{t}} \ldots \ldots \ldots \ldots \ldots \ldots \ldots(5)
\end{aligned}
$$

where,

$\mathrm{Z}_{\mathrm{t}}=$ an $\mathrm{n} \mathrm{x} 1$ vector of variables, in our case, $Z_{t}=(Y, I N F)$.

$\delta=$ an $\mathrm{n} \times 1$ vector of constant, respectively.

$\Gamma=$ an $n \times n$ matrix (coefficients of the short run dynamics),

$\Pi=\alpha \beta^{\prime}$

where a is an $n \times 1$ column vector (the matrix of loadings) represents the speed of short run adjustment to disequilibrium and $\beta^{\prime}$ is an $1 \times n$ cointegrating row vector (the matrix of cointegrating vectors) indicates the matrix of long run coefficients such that $Z_{t}$ converge in their long run equilibrium. Finally, $\varepsilon_{t}$ is an $n \times 1$ vector of white noise error term and $k$ is the order of autoregression.

A test statistic is calculated by taking the sum of the squared F-statistics of $\Gamma$ and t-statistics of $\Pi$. The multivariate causality test is implemented by calculating the F-statistics (Wald-test) based on the null-hypothesis that the set of coefficients $(\Gamma)$ on the lagged values of independent variables are not statistically different from zero. If the null-hypothesis is not rejected, then it can be concluded that the independent variables do not cause the dependent variable. On the other hand, if $\Pi$ is significant (that is different from zero) based on the t-statistics, then both the independent and depen- dent variables have a stable relationship in the long-run.

From Equation (5) two channels of causation may be observed. The first channel is the standard Granger tests, examining the joint significance of the coefficients of the lagged independent variables. Whereas, the second channel of causation is the adjustment of the dependent variable to the lagged deviations from the long run equilibrium path, represented by the error correction term (ECT). If the ECT is found to be significant, it substantiates the presence of cointegration as established in the system earlier and at the same time; it tells us that the dependent variable adjusts towards its long run level. From these tests, we can reveal four patterns of causal interactions among pairs of the variables, i.e., (i) a unidirectional causality from a variable, say $\mathrm{x}$, to another variable, say y; (ii) a unidirectional causality from y to $x$; (iii) bidirectional causality; and (iv) independent causality between $\mathrm{x}$ and $\mathrm{y}$.

\section{Results and Discussion}

\section{Graphical Plots}

Using graphical plots, we observe the behavior of outputs and prices in the ASEAN-5 countries over the period from 1990 to 2006. While the observations can be rather subjective, several general trends can be made with regard to the output-price relationship in these countries. Prices in 
Kassim \& Abd. Majid-Output-Price Dynamics in the ASEAN-5 Countries

all these countries touched a historical high during the crisis in 1997-1998, thus providing the justification for us to exclude the crisis period in our analysis. Based on the graphical plots, there is a clear negative relationship between outputs and prices in Malaysia, Indonesia and Thailand. However, for Singapore and the Philippines, the graphical plots seem to indicate a clearer positive relationship between outputs and prices after the crisis than before the crisis. These observations are preliminary and needed quantitative support to ensure their validity.

Figure 1. Graphical Plots of Outputs and Prices in the ASEAN-5 Countries, 1990-2006

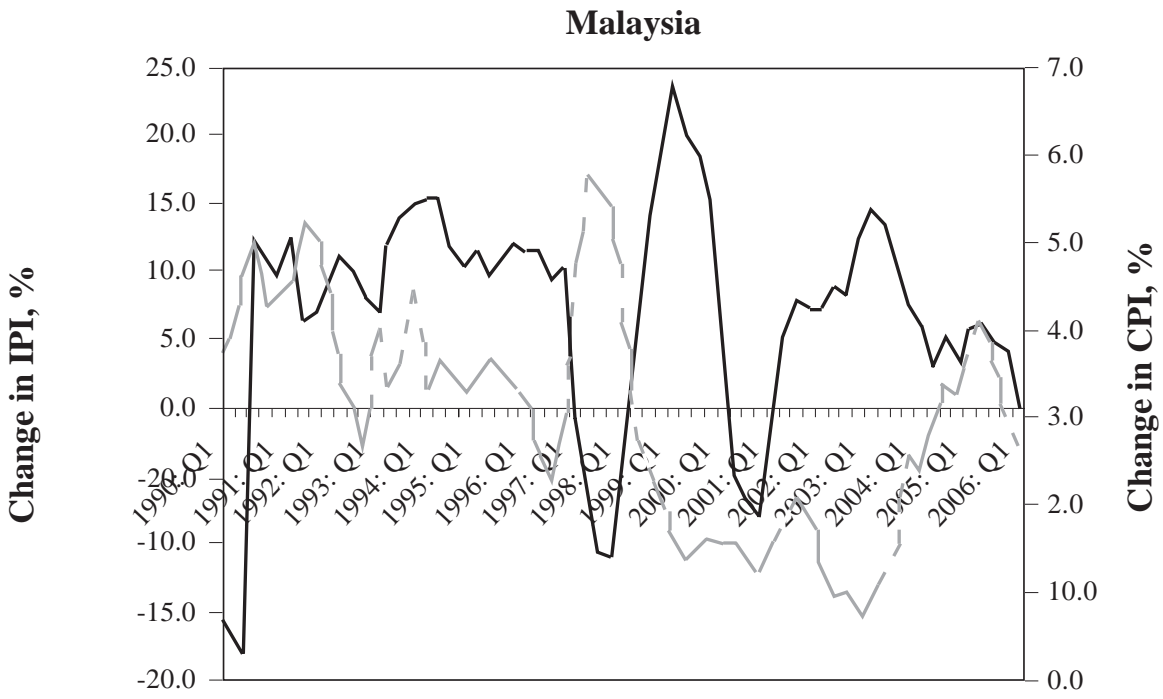

-IPI - - -CPI 
Gadjah Mada International Journal of Business, May - August 2008, Vol. 10, No. 2

\section{Continued from Figure 1}
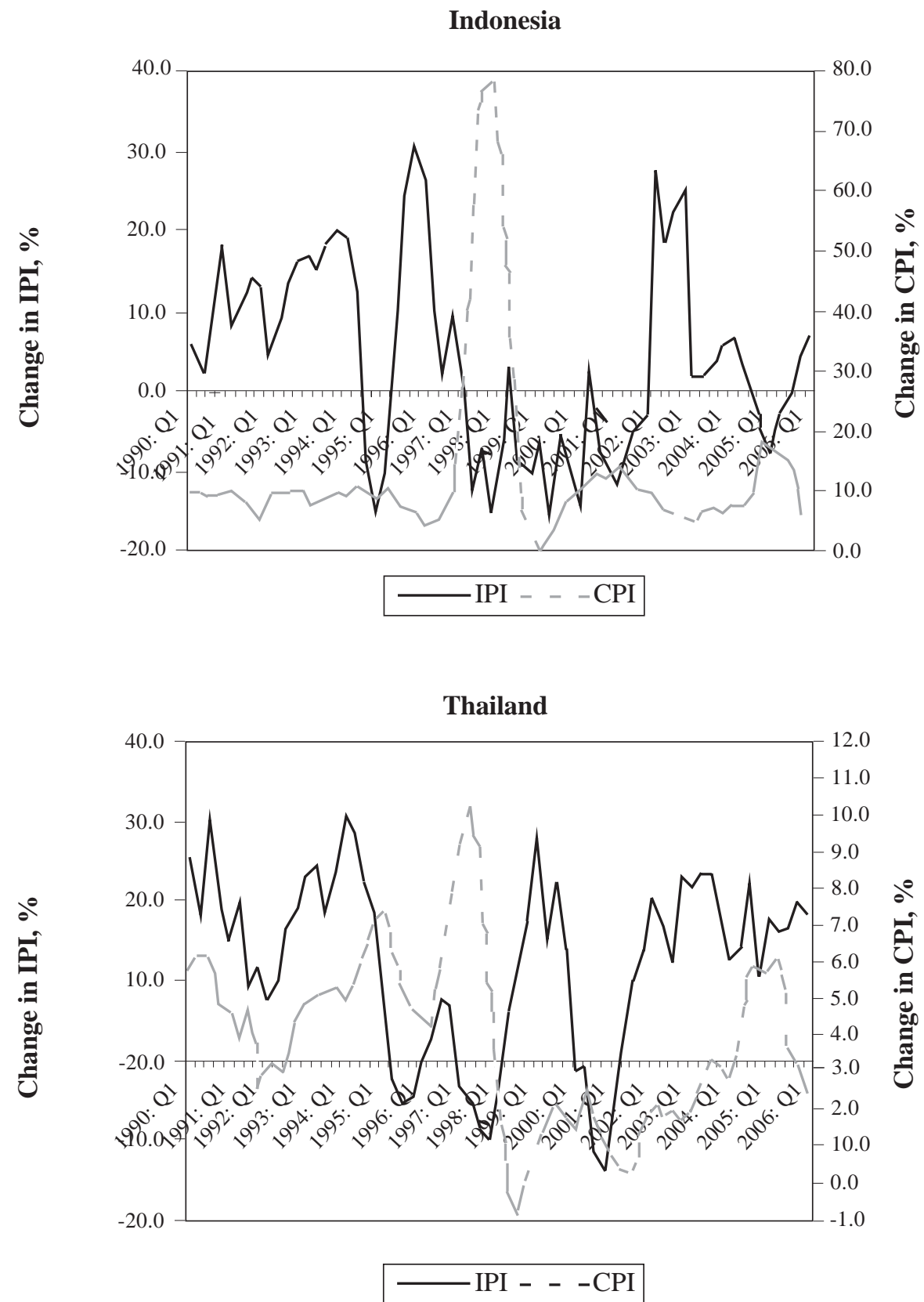
Kassim \& Abd. Majid-0utput-Price Dynamics in the ASEAN-5 Countries

\section{Continued from Figure 1}

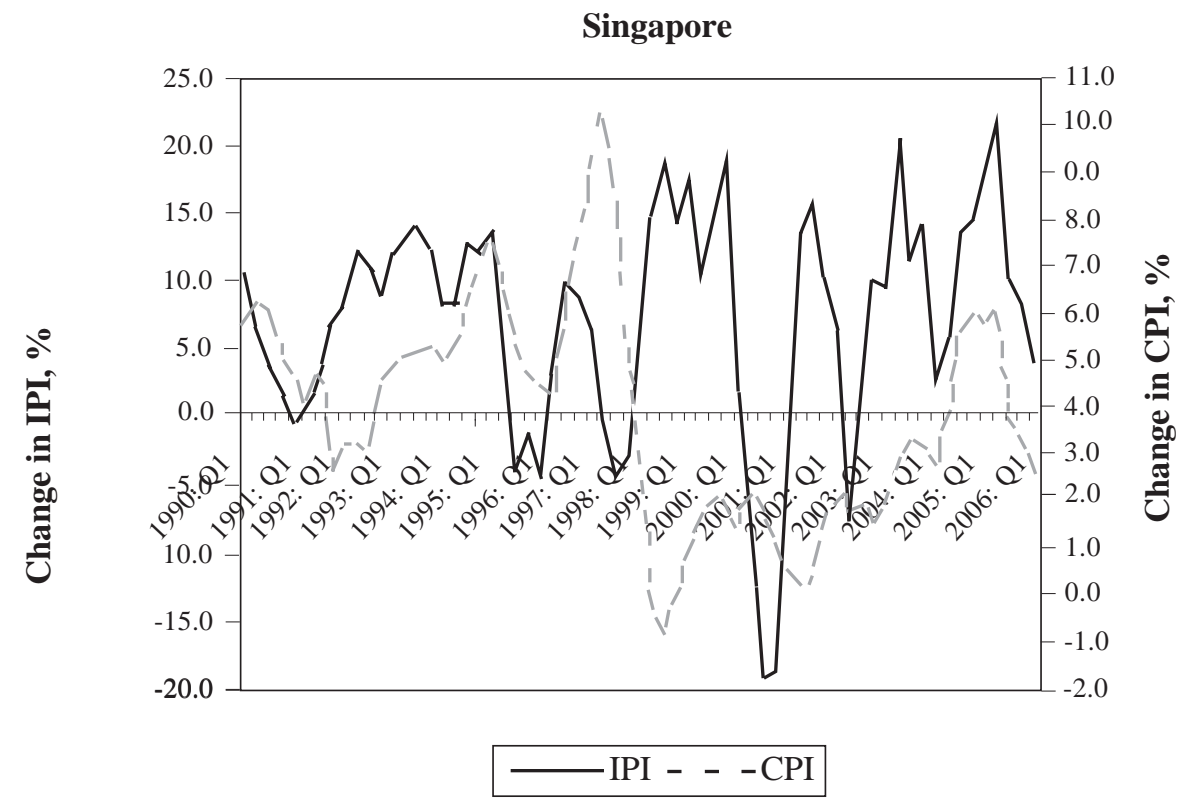

The Philippines

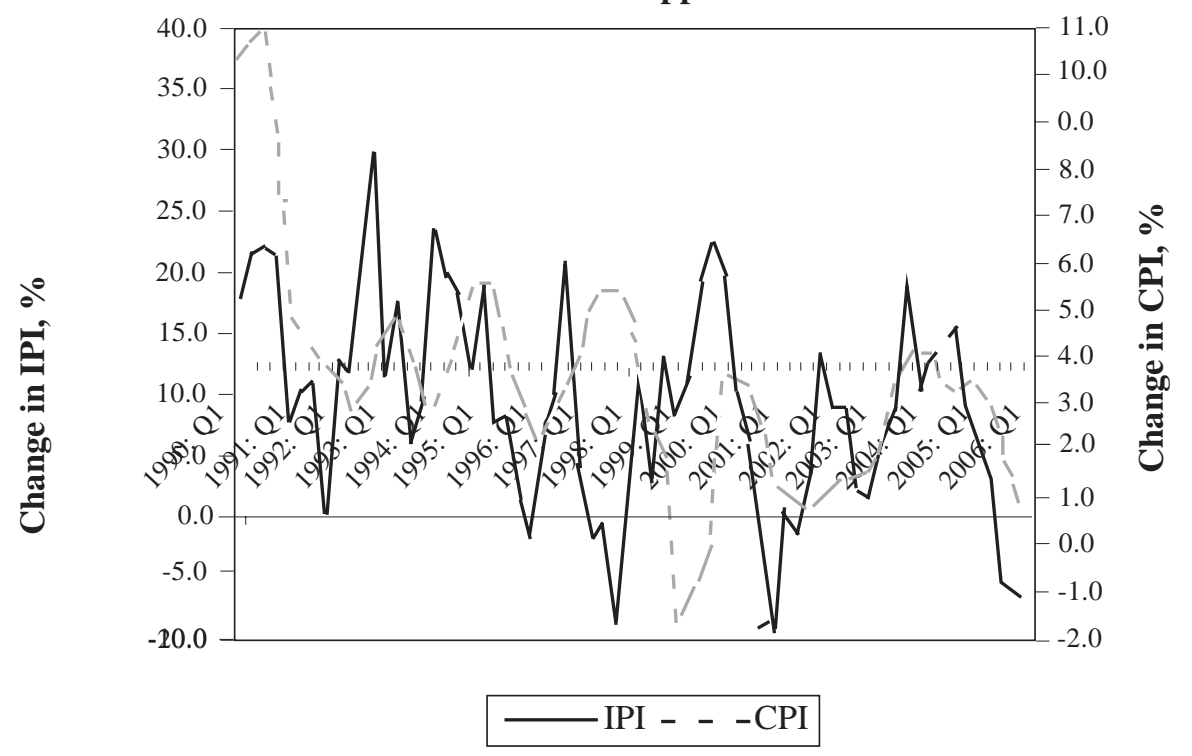


Gadjah Mada International Journal of Business, May - August 2008, Vol. 10, No. 2

\section{Pearson Correlation Analysis Results}

The correlation analysis is a shortrun analysis that helps to quantify the relationship between the variables, while at the same time indicates the strength and direction of the relationship between the variables. Interestingly, the correlation results are supportive of the earlier observations based on the plots of trends in output and prices (Table 1). In the pre-crisis period, the correlation of coefficients for the individual countries showed that outputs and prices are negatively related in Indonesia, Malaysia and the Philippines, while positive correlations are observed for Singapore and Thailand. After the region was hit by the crisis in 1997-1998, the correlation of coefficients between outputs and prices become stronger in all the ASEAN-5 countries, with stronger negative relationships being observed in Indonesia, Malaysia and the Philippines and stronger positive relationships between outputs and prices in Singapore and the Philippines. The anti-cyclical behavior between output and price in Indonesia, Malaysia and the Philippines suggests the predominance of supplyside shocks in causing macroeconomic fluctuations. In these countries, the impact of high inflationary pressure affects the production side of the economy, resulting in lower aggregate. In view of this, effective economic policy during an economic downturn would be to formulate policies that are favoring the production side such as giving tax incentive to the corporate to reduce cost of doing business or giving subsidies for the raw materials in efforts to reduce the costs of inputs.

The analysis however, shows that there is positive output-price relationship for Singapore and Thailand and the positive relationship gets stronger in the post-crisis period. In contrast to Indonesia, Malaysia and the Philippines, this result suggests the importance of demand-shocks in macroeconomic fluctuations in Singapore and Thailand. The dominance of demand shocks in influencing economic activity in these countries suggest that policies directed towards stimulating aggregate demand are more effective in reviving the economy. This includes income tax reduction for the consumers and supportive export polices to strengthen the external demand.

The correlation analysis also allows us to make further inferences on the output-price relationship in the context of economic integration. In this regard, we determine if the output of the individual country is correlated with the rest of the ASEAN countries in the pre- and post-crisis periods. The results show that, in the short run, the outputs of all the ASEAN-5 countries are positively correlated with the others, both in the pre- and post-crisis periods. For example, Indonesian output correlates positively to the rest of the ASEAN countries in both periods. Similarly, price level of the individual country is also positively correlated to 
Kassim \& Abd. Majid-Output-Price Dynamics in the ASEAN-5 Countries

Table 1. Correlation of the Real Output and Inflation among the ASEAN-5 Countries

\begin{tabular}{|c|c|c|c|c|c|c|c|c|c|c|}
\hline & $Y_{I}$ & $\mathbf{Y}_{\mathrm{M}}$ & $Y_{P}$ & $\mathbf{Y}_{\mathrm{s}}$ & $\mathbf{Y}_{\mathrm{T}}$ & $\mathrm{INF}_{\mathrm{I}}$ & $\mathrm{INF}_{\mathrm{M}}$ & $\mathrm{INF}_{\mathrm{P}}$ & $\mathrm{INF}_{\mathrm{s}}$ & $\mathrm{INF}_{\mathrm{T}}$ \\
\hline $\mathbf{Y}_{\mathrm{I}}$ & - & 0.358 & 0.127 & 0.101 & 0.536 & -0.623 & -0.224 & 0.095 & 0.237 & 0.339 \\
\hline $\mathbf{Y}_{\mathrm{M}}$ & 0.464 & - & 0.379 & 0.488 & 0.850 & -0.367 & -0.387 & -0.101 & 0.125 & 0.025 \\
\hline $\mathbf{Y}_{\mathbf{p}}$ & 0.110 & 0.263 & - & 0.671 & 0.326 & 0.014 & -0.071 & -0.045 & 0.461 & 0.272 \\
\hline $\mathbf{Y}_{\mathrm{s}}$ & 0.339 & 0.351 & 0.188 & - & 0.470 & -0.026 & 0.180 & -0.272 & 0.316 & 0.283 \\
\hline $\mathbf{Y}_{\mathrm{T}}$ & 0.335 & 0.313 & 0.323 & 0.406 & - & -0.480 & -0.236 & -0.027 & 0.263 & 0.205 \\
\hline $\mathrm{INF}_{\mathrm{I}}$ & -0.597 & -0.306 & 0.199 & -0.260 & -0.102 & - & 0.167 & 0.030 & 0.060 & -0.204 \\
\hline $\mathrm{INF}_{\mathrm{M}}$ & -0.195 & -0.161 & -0.444 & -0.498 & -0.383 & 0.015 & - & 0.339 & 0.025 & 0.404 \\
\hline $\mathrm{INF}_{\mathrm{p}}$ & -0.117 & -0.199 & -0.001 & -0.286 & 0.149 & 0.071 & 0.336 & - & 0.295 & 0.213 \\
\hline $\mathrm{INF}_{\mathrm{S}}$ & 0.001 & -0.075 & 0.101 & 0.077 & -0.013 & 0.130 & 0.256 & 0.281 & - & 0.373 \\
\hline $\mathrm{INF}_{\mathrm{T}}$ & -0.033 & 0.199 & 0.193 & 0.473 & 0.055 & 0.022 & 0.065 & 0.068 & 0.253 & - \\
\hline
\end{tabular}

Notes: Y and INF represent real output and inflation, while subscripts ${ }_{\mathrm{I}, \mathrm{M}, \mathrm{P}, \mathrm{S}, \mathrm{T}}$ indicate Indonesia, Malaysia, the Philippines, Singapore, and Thailand, respectively. The lower diagonal provides correlation coefficients for pre-crisis period, while the upper diagonal provides correlation coefficients for post-crisis period. The figures in bold in the top-diagonal indicate the cases of increased correlations. The figures in italic indicate the cases of changed in correlation sign.

the rest of the ASEAN countries, except for the prices of Indonesia and Thailand which have a negative relationship. In general, it can be concluded that the outputs of these countries tend to have similar cycles and so do their prices. Further inferences on the cyclical behavior of output and prices among these countries can only be made after the application of the cointegration test based on the ARDL model.

\section{Cointegration Results Based on the ARDL}

In this section, we present the findings of the cointegration test based on the ARDL model (Table 2). For the pre-crisis period, the computed F-sta- tistics are found to be significant for both Malaysia and the Philippines at lag length $=6$, implying that output and price are cointegrated in the long run for these countries. This finding indicates the existence of a long-run equilibrium between output and price in Malaysia and the Philippines. In the post-crisis period, output and price seem to be cointegrated only in the case of Indonesia and not in the rest of the countries. Thus, recent data suggests that there is a change in the longrun relationship between output and price in the major ASEAN countries following the financial crisis 1997/ 1998. In particular, the cointegrating relationship between output and price for Malaysia and the Philippines has 
Gadjah Mada International Journal of Business, May - August 2008, Vol. 10, No. 2

Table 2. F-statistics for ARDL Cointegration Test between Real Output and Inflation

\begin{tabular}{|c|c|c|c|c|c|}
\hline \multirow{2}{*}{$\begin{array}{c}\text { Lag- } \\
\text { Length }\end{array}$} & \multicolumn{5}{|c|}{ Pre-Crisis Period } \\
\hline & Indonesia & Malaysia & Philippines & Singapore & Thailand \\
\hline 1 & 3.4415 & 0.2604 & 1.4436 & 0.2654 & 1.1175 \\
\hline 2 & 2.4263 & 1.0043 & 0.5612 & 0.0197 & 1.3655 \\
\hline 3 & 1.7058 & 0.8617 & 0.6667 & 0.5469 & 1.3041 \\
\hline 4 & 1.2249 & 0.6869 & 0.8490 & 0.2522 & 0.8299 \\
\hline 5 & 0.9311 & 1.6069 & 0.9157 & 0.2043 & 1.1718 \\
\hline 6 & 0.3263 & $6.3492^{* *}$ & $17.3927^{*}$ & 0.0142 & 2.8856 \\
\hline \multicolumn{6}{|c|}{ Post-Crisis Period } \\
\hline 1 & 3.6419 & 0.2626 & 2.5897 & 0.4947 & 0.3989 \\
\hline 2 & 2.8468 & 0.2986 & 1.8979 & 0.01446 & 0.6002 \\
\hline 3 & $5.0535^{* *}$ & 1.4894 & 0.7774 & 0.6691 & 0.1278 \\
\hline 4 & 3.1545 & 2.0625 & 1.7394 & 0.4210 & 0.1790 \\
\hline 5 & $4.6880^{* *}$ & 0.6547 & 0.5301 & 1.9502 & 0.8382 \\
\hline 6 & $6.8360^{*}$ & 0.6088 & 0.1884 & 3.4389 & 1.9165 \\
\hline
\end{tabular}

Notes: The relevant critical value bounds are taken from Case II with a restricted intercept and no trend and number of regressors $=3$ (Narayan 2004). They are 6.027 - 6.760 at the 99 percent; 4.090-4.663 at the 95 percent; and 3.303-3.797 at the 90 percent significance levels respectively. *, **, and *** denote that F-Statistics falls above the 90 percent, 95 percent and 99 percent upper bounds, respectively.

turned to be insignificant after the region was hit by the financial crisis. This could imply a lesser degree of cointegration among the ASEAN countries partly due to the different macroeconomic stabilization policies adopted by the individual countries.

\section{Long-Run ARDL Estimates Results}

The next step involves estimating the equations for Malaysia and the
Philippines (for the pre-crisis period) and Indonesia (for the post-crisis period) which outputs and prices have shown significant cointegrating relationship earlier. For more detailed inference, we report the long-run ARDL model estimates of real output and prices for these countries in Table 3.

The findings show that inflation is insignificant in affecting output in Malaysia and the Philippines as reflected by the insignificant t-statistics 
Kassim \& Abd. Majid-Output-Price Dynamics in the ASEAN-5 Countries

Table 3. Long Run ARDL Model Estimates between Real Output and Inflation

\begin{tabular}{|c|c|c|c|}
\hline \multirow[b]{2}{*}{ Country } & \multicolumn{2}{|c|}{ Pre-Crisis Period } & \multirow{2}{*}{ 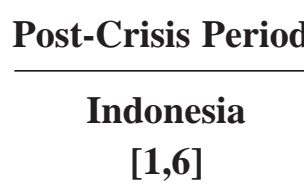 } \\
\hline & $\begin{array}{c}\text { Malaysia } \\
{[6,6]}\end{array}$ & $\begin{array}{c}\text { Philippines } \\
{[1,0]}\end{array}$ & \\
\hline Constant & $\begin{array}{l}1.0721 * \\
(5.9433)\end{array}$ & $\begin{array}{l}-1.1744 * * \\
(-2.3197)\end{array}$ & $\begin{array}{l}-0.04663 \\
(-0.5502)\end{array}$ \\
\hline Inflation & $\begin{array}{c}1.0721 \\
(-1.4532)\end{array}$ & $\begin{array}{c}2.3222 \\
(0.3646)\end{array}$ & $\begin{array}{c}-9.3329 * * \\
(2.5808)\end{array}$ \\
\hline & $\begin{array}{l}\text { Adj-R }=0.516 \\
D-W=1.7863\end{array}$ & $\begin{array}{c}\text { Adj-R }=.0 .6369 \\
D-W=2.3209\end{array}$ & $\begin{array}{c}\text { Adj-R }=0.7933 \\
D-W=2.5757\end{array}$ \\
\hline
\end{tabular}

Notes: *, ** and *** denote significance at $10 \%, 5 \%$ and $1 \%$ levels of significance, respectively. Figures in the parentheses and squared parentheses are the $t$-statistics values and the selected ARDL model. D-W denotes Durbin-Watson test for autocorrelation.

of both countries during the pre-crisis period. However, in the post-crisis period, the negatively significant $\mathrm{t}$ statistics for Indonesia clearly suggests that in the long-run, inflation is detrimental to the Indonesian economy. This finding supports our earlier results on the negative correlation between output and price in the Indonesian case. Our finding implies that the relatively higher rate of inflation in Indonesia during the post-1997 financial crisis as compared to other ASEAN countries has been an obstacle for the government to promote economic development. ${ }^{1}$ This finding concurs well with several empirical studies which document positive relationship between output and inflation (Bekaert et al. 2005; and Hung 2003), while high inflation about $10-20$ percent per annum would adversely affect the longrun economic growth (Gylfason et al. 2001; and Andrés et al. 2004). Indeed, this study provides an empirical support that it is very crucial for the Indonesian government to maintain price stability by reducing the rate of inflation below two digits in efforts to promote economic growth. A significant increase in the prices of petroleum and cooking oil in the early 2005 and mid-

\footnotetext{
${ }^{1}$ See, for example, the IMF report for the year 2005. The average rate of inflation for Indonesia was 10.45 percent, while the rates of inflation of the rest of the ASEAN countries were between 0.5- 9.4 percent, i.e., Brunei Darussalam (1.22\%), Malaysia (2.96\%), Cambodia (5.56\%), Laos (7.17\%), Myanmar (9.37\%), the Philippines (7.64\%), Singapore (0.47\%), Thailand (4.54\%) and Vietnam (8.25\%).
} 
Gadjah Mada International Journal of Business, May - August 2008, Vol. 10, No. 2

2006, respectively had hindered the growth of the Indonesian economy and it has also become one of obstacles for the government to totally recover the economy.

\section{Multivariate VECM Results}

For further inferences, we adopt the multivariate causality analysis based on the VECM which enable us to explore both the short- and long-run dynamics of the variables among the countries. Here, we regressed the changes in both the dependent and independent variables on lagged deviations as in the Equation 5. The estimates of the error correction representations are presented in Table 4. The long-run coefficients reported for all the models are employed to generate the error correction terms. The computed F-statistics clearly reject the null hypothesis that all regressors have zero coefficients for both cases.

For Malaysia, the short-run analysis shows there is no significant relationship between output and prices, but there is a significant negative relationship between output and price in the long-run as shown by the significant negative ECT. For the Philippines, the short-run causality also shows no significant relationship between output and price, but significant negative relationship between the two variables in the long run. These results are consistent with the earlier findings that documented the importance of supply-side shocks in both Malaysia and the Philippines. In the post-crisis period, the short-run causality shows no significant relationship between output and price in Indonesia, but a significant negative relationship be-

Table 4. VECM Causality between Real Output and Inflation

\begin{tabular}{|c|c|c|c|c|c|c|c|c|c|}
\hline \multirow{4}{*}{ 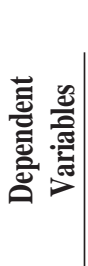 } & \multicolumn{9}{|c|}{ Independent Variables } \\
\hline & \multicolumn{6}{|c|}{ Pre-Crisis Period } & \multicolumn{3}{|c|}{ Post-Crisis Period } \\
\hline & \multicolumn{2}{|c|}{ Malaysia } & \multirow[t]{2}{*}{$\mathrm{ECT}_{\mathrm{t}-1}$} & \multicolumn{2}{|c|}{ Philippines } & \multirow[t]{2}{*}{$\mathrm{ECT}_{\mathrm{t}-1}$} & \multicolumn{2}{|c|}{ Indonesia } & \multirow[t]{2}{*}{$\mathrm{ECT}_{\mathrm{t}-1}$} \\
\hline & $\Delta \mathbf{Y}$ & $\Delta \mathrm{INF}$ & & $\Delta \mathrm{Y}$ & $\Delta \mathrm{INF}$ & & $\Delta \mathbf{Y}$ & $\Delta \mathrm{INF}$ & \\
\hline$\Delta \mathrm{Y}$ & - & $\begin{array}{c}0.2285 \\
{[0.8750]}\end{array}$ & $\begin{array}{c}0.0008 \\
(1.6912)\end{array}$ & - & $\begin{array}{c}2.3975 \\
{[0.1764]}\end{array}$ & $\begin{array}{l}-0.0180^{*} \\
(-2.0379)\end{array}$ & - & $\begin{array}{c}2.2740 \\
{[0.1914]}\end{array}$ & $\begin{array}{c}-0.4258 \\
(-1.1978)\end{array}$ \\
\hline$\Delta \mathrm{INF}$ & $\begin{array}{c}1.5454 \\
{[0.3265]}\end{array}$ & - & $\begin{array}{c}-0.7573 * * \\
(-2.8000)\end{array}$ & $\begin{array}{c}0.7189 \\
{[0.5543]}\end{array}$ & - & $\begin{array}{c}0.2853 \\
(0.2678)\end{array}$ & $\begin{array}{c}2.6828 \\
{[0.1474]}\end{array}$ & - & $\begin{array}{l}-0.6606^{*} \\
(-2.0974)\end{array}$ \\
\hline
\end{tabular}

Notes: $* * *, * *$ and $*$ represent significance at the 1 percent, 5 percent, and 10 percent levels, respectively. $\mathrm{ECT}_{\mathrm{t}-1}$ is derived by normalizing the cointegrating vectors on the dependent variables, producing residual $r$. By imposing restriction on the coefficients of each variable and conducting Wald test, we obtain $F$-statistics for each coefficient in all equations. Figures in the parentheses and squared parentheses represent $t$-statistics and probabilities for $F$-statistics, respectively. 
tween the two variables in the long run as shown by the significant ECT. Our findings indicate that if policy makers want to promote growth, attention should be focused on long-run policies i.e., maintaining the low rate of inflation.

\section{Diagnostic Test Results}

To examine the stability of the long-run coefficients, we apply the Cumulative Sum of Recursive Residuals (CUSUM) and Cumulative Sum of Recursive Residuals Squared (CUSUM-SQ) tests proposed by Brown et al. (1975). The tests are employed for all the models involved. As highlighted by Bahmani-Oskooee and Ng (2002), the CUSUM and CUSUM-SQ test employs the cumulative sum of recursive residuals based on the first set of observations and is updated recursively and plotted against the break points. If the plots of the CUSUM and CUSUM-SQ statistics are found to be within the critical bounds of 5 percent level, the null hypothesis that all coefficients in the models are stable cannot be rejected. On the other hand, if the lines are found to be crossed, the null hypothesis of coefficient constancy can therefore be rejected at 5 percent significance level. Based on the graphical representations for CUSUM and CUSUM-SQ tests for all models, the results indicate no evidence of any significant structural instability. ${ }^{2}$ This indicates that the estimated models in this study are satisfactorily providing robust results.

\section{Conclusion and Policy Implications}

This study attempts to determine the relationship between output and price in major ASEAN economies, namely Malaysia, Indonesia, Thailand, Singapore and the Philippines. Having a clear idea on the output-price relationships helps us to empirically identify the major sources of macroeconomic fluctuations in these countries. The study considers two sample periods, namely the pre-crisis and postcrisis with the aim to identify if there are changes in the patterns of the correlation between output and prices in the two sample periods in these economies. Apart from understanding the relationship between output and price in these countries, the study also attempts to find empirical support for the existence of business cycles synchronization across the ASEAN-5 countries.

Results from the various tests undertaken in this study show several interesting findings. The graphical plots show similar patterns of outputprice relationship in Indonesia, Malaysia and Thailand, with their outputs and prices being negatively related. On contrary, outputs and prices are being positively correlated in

\footnotetext{
${ }^{2}$ To conserve space, the plots of these tests are not provided in this study. However, they are available upon request from the authors.
} 
Singapore and the Philippines. The results from the Pearson correlation analysis show that outputs and prices are negatively correlated in Indonesia, Malaysia and the Philippines, while they are positively correlated in Singapore and Thailand. While the nature of outputs and prices relationship remains similar in the pre and post-crisis periods, the strength of the relationship gets stronger in the postcrisis period. Moving on to the more detailed tests, the ARDL estimation results show that significant outputprice relationship is evidenced only in Malaysia and the Philippines in the pre-crisis period, while in the postcrisis period, only Indonesia recorded significant negative relationship between the two variables.

Several major policy implications can be drawn from the findings of this study. First, it is important to note that for many of the ASEAN economies, the output-price relationship within the countries have changed following the crisis in 1997/1998. This entails that increased efforts need to be done in achieving business cycles synchronization in the ASEAN-5 countries. Second, as suggested by the results from the several tests conducted in this study, demand shocks are predominant in Indonesia, Malaysia and the Philippines, while supply-shocks are pre- dominant in Singapore and Thailand. Thus, macroeconomic policy which favors the production side of the economy is more suitable in Indonesia, Malaysia and the Philippines, while polices that stimulate the demand or consumption side are more effective for Singapore and Thailand. The dichotomy in the output-price relationships in these two groups in ASEAN implies that different prescriptions are needed in the macroeconomic management in these countries. As such, ASEAN has yet to achieve the level of macroeconomicintegration that would allow a similar macroeconomic prescription to be implemented for the group. This result implies that macroeconomic policy harmonization could be cumbersome in view of the different sources of macroeconomic fluctuations in these countries. Third, while the high inflation environment in Indonesia seems not to be affecting its neighboring countries, results of this study suggest that it could adversely affect the economic performance of the other country if this condition were to be considered at the ASEAN scale. In other words, to achieve the benefits of economic integration, serious efforts need to be done at the individual country level to ensure that some levels of macroeconomic convergence are achieved. 
Kassim \& Abd. Majid-Output-Price Dynamics in the ASEAN-5 Countries

\section{References}

Andrés, J., I. Hernando, and J. D. Lo'pez-Salido. 2004. The role of the financial system in the growth-inflation link: the OECD experience. European Journal of Political Economy 20: 941-961.

Backus, D. K., and P. J. Kehoe. 1992. International evidence on the historical properties of business cycles. American Economic Review 82: 864-885.

Bahmani-Oskooee, M., and M. T. Bohl. 2000. German monetary unification and the stability of the German M3 money demand function. Economics Letters 66: 203-208.

Bahmani-Oskooee, M., and R. C. W. Ng. 2002. Long-run demand for money in Hong Kong: An application of the ARDL model. International Journal of Business and Economics 1 (2): 147-155.

Bekaert, G., C. R. Harvey, and C. Lundblad. 2005. Does financial liberalization spur growth? Journal of Financial Economics 77 (30): 3-55.

Chada, B., and E. Prasad. 1993. Interpreting the cyclical behavior of prices. IMF Staff Papers 40: 266-298.

Cooley, T. F., and L. E. Ohanian. 1991. The cyclical behavior of prices. Journal of Monetary Economics 28: 25-60.

Cover, J. P., and C. J. Hueng. 2001. The correlation between shocks to output and the price level: evidence from a GARCH model. Working Paper Series. The University of Alabama.

Den Haan, W.J., and S. Sumner. 2001. The comovements between real activity and prices in the G7. NBER Working Paper Series 8195. National Bureau of Economic Research.

Engle, R. F. 2002. Dynamic conditional correlation-a simple class of multivariate GARCH models. Journal of Business and Economic Statistics 20: 339-350.

Fiorito, R., and T. Kollintzas. 1994. Stylized facts of business cycles in the G7 from a real business cycles perspective. European Economic Review 38: 253-269.

Friedman, M. 1968. The role of monetary policy. American Economic Review 58: 1-17.

Gylfason, T., and T. T. Herbertsson. 2001. Does inflation matter for growth? Japan and World Economy 13: 405-428.

Hung, F. S. 2003. Inflation, financial development, and economic growth. International Review of Economics and Finance 12: 45-67.

International Monetary Fund. 2006. International Financial Statistic Online: www.imfstatistics.org.

Jun, S. 1992. Money, prices and nominal wages: long run and short run dynamics. Korea Development Institute Studies: 789-797.

Kim, Y. W. 1996. Are prices countercyclical: evidence from East Asia countries. Federal Reserve Bank of St Louis Review 78: 69-82.

Kydland, F. E., and E. C. Prescott. 1990. Business cycles: Real facts and a monetary myth. Federal Reserve Bank of Minneapolis Quarterly Review 15: 3-18. 
Gadjah Mada International Journal of Business, May - August 2008, Vol. 10, No. 2

Laurenceson, J., and J. C. H. Chai. 2003. Financial Reform and Economic Development in China. Cheltenham, UK: Edward Elgar.

Lee, J. 2006. The comovement between output and prices: Evidence from a dynamic conditional correlation GARCH model. Economic Letters 91: 110-116.

Moore, G. H. 1983. Business Cycles, Inflation and Forecasting ( $2^{\text {nd }}$ Edition). Cambridge, Massachusetts: Ballinger Publishing.

Narayan, P. K. 2004. Reformulating critical values for the bounds F-statistics approach to cointegration: An application to the tourism demand model for Fiji. Discussion Paper No. 02/04. Department of Economics, Monash University.

Pesaran, M. H., and B. Pesaran. 1997. Working with Microfit 4.0: Interactive Econometrics Analysis. Oxford University Press.

Pesaran, M. H., Y. Shin, and R. J. Smith. 1996. Testing for the existence of a long-run relationship. DAE Working Paper No. 9622. Department of Applied Economics, University of Cambridge.

Phelps, E. S. 1967. Phillips curves, expectations of inflation and optimal unemployment over time. Economica 24: 254-281.

Smith, R. T. 1992. The cyclical behavior of prices. Journal of Money, Credit and Banking 24 (4): 413-430.

Wolf, H. C. 1991. Procyclical prices: A demi-myth? Federal Reserve Bank of Minneapolis Quarterly Review 15: 25-28.

Yoo, B. S. 1992. Effects of demand and supply shocks on the Korean economy. Monetary and Financial Studies Working Paper No. 52. Bank of Korea Institute for Monetary and Economic Research.

Zarnowitz, V., and G. H. Moore. 1983. Major changes in cyclical behavior. In edited by Robert J. Gordon (edited), The American Business Cycle: Continuity and Change, Chicago: University of Chicago Press. 